تحليل مصارف انرزى در روشهاى مختلف بهرهبردارى از ايستخاههاى يمياز آب كثاورزى (مطالعه موردى: سامانه آبيارى كشت و صنعت اشرفيه)

افشين يوسف گمر كجى "* و عاطفه يرورش ريزى'

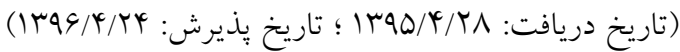

جكيده

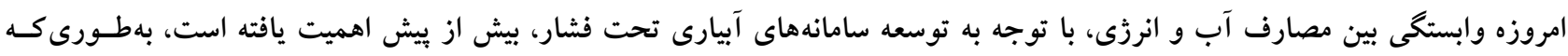

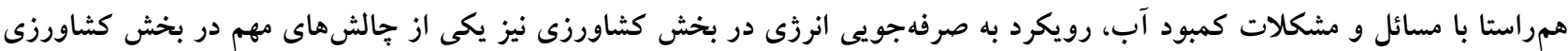

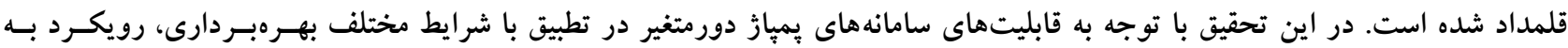

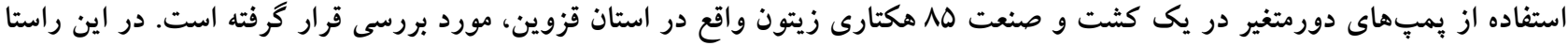

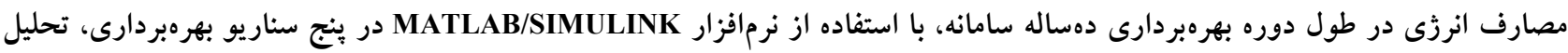

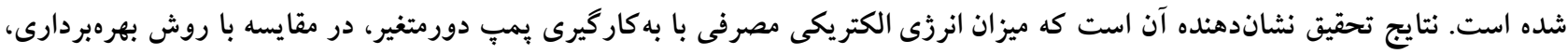

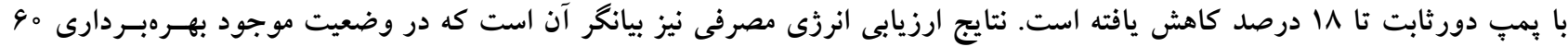

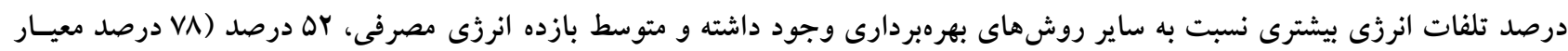

وازمهاى كليدى: يمب دورمتغير، سيمولينك، صرفهويى انررى، مدلسازى، معيار نبراسكا

1. بخش تحقيقات فنى و مهندسى كشاورزى، مركز تحقيقات و آموزش كشاورزى و منابع طبيعى استان قزوين، سازمان تحقيقات، آموزش و ترويج كشاورزى، قزوين، ايران

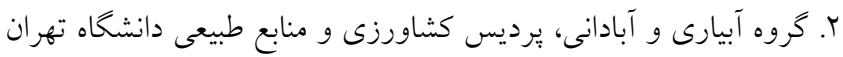

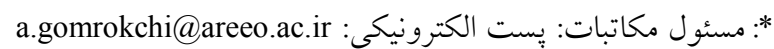




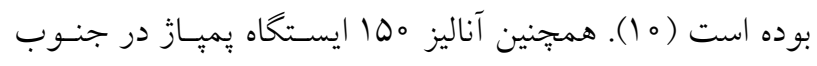

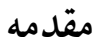

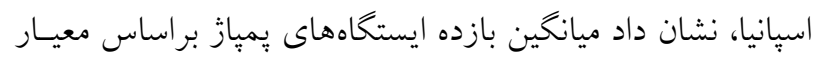

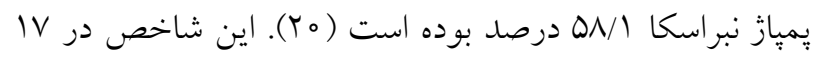

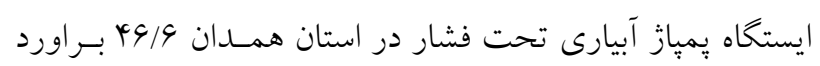

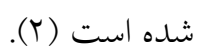

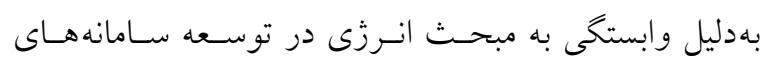

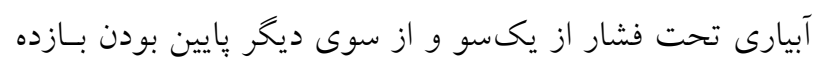

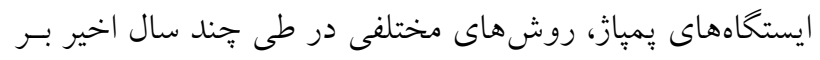

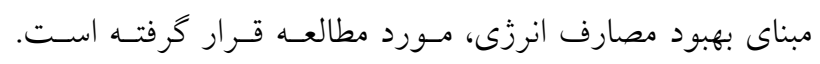

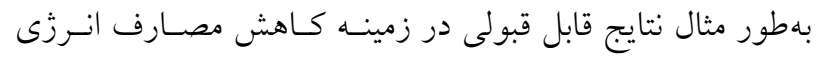

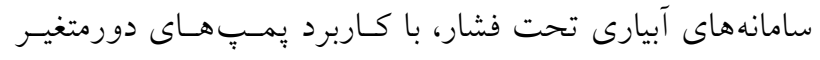
كـزارش شــده اسـت (IV). در تحقيقسى اثربخشسى اسـتفاده از

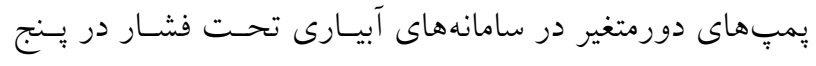

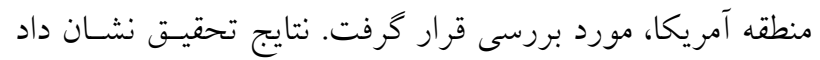

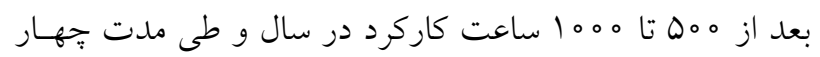

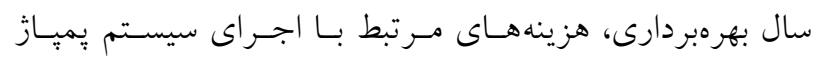

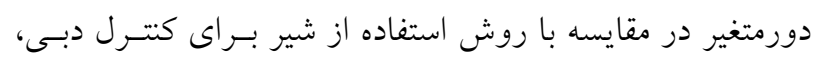
قابل توجيه است. مصرف انرزى بخششهاى مورد مطالعهـ نشـان

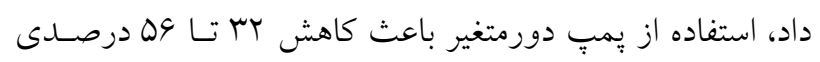

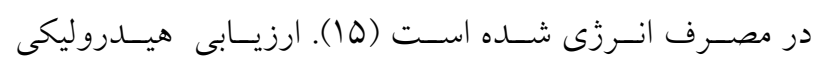

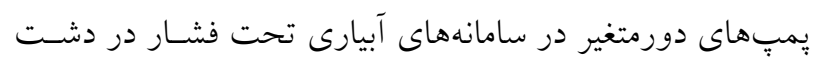

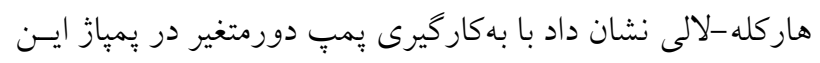

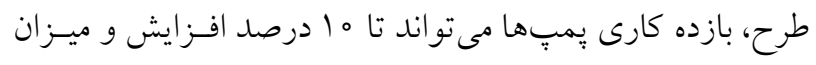

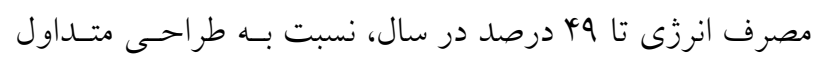

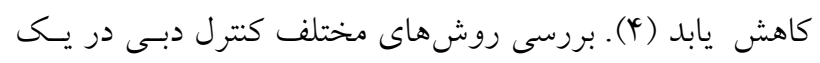

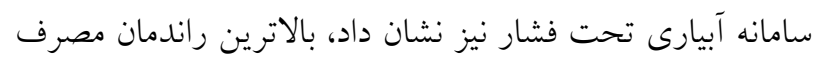

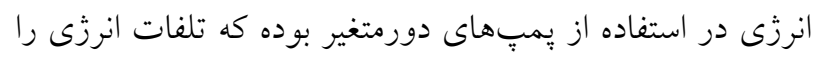

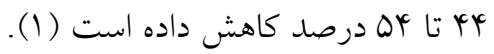

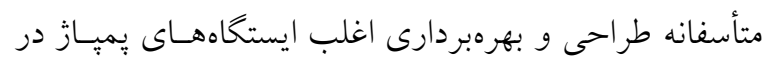

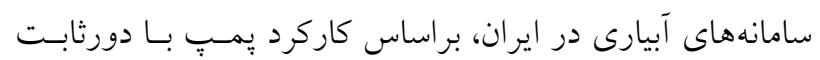

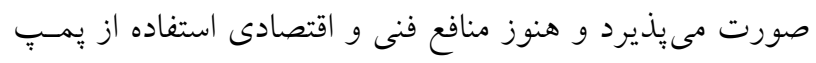

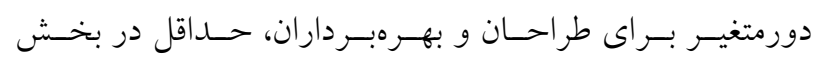

وابستخى به مبحث انرزى در توسعه سامانههـاى آبيـارى تحـت

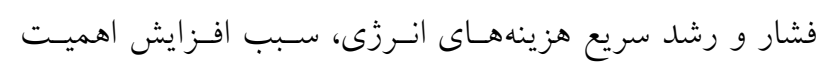

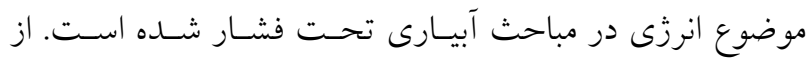

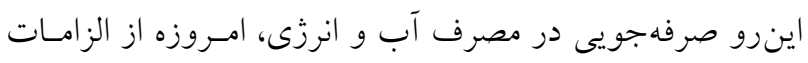

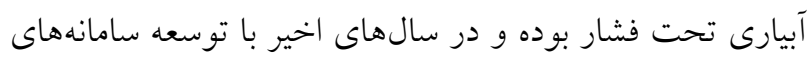

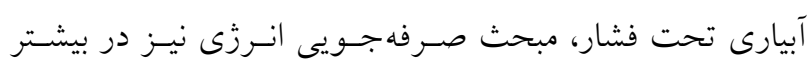

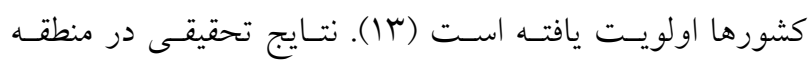

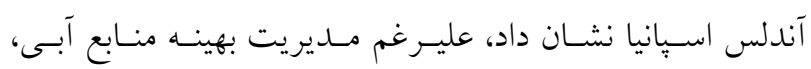

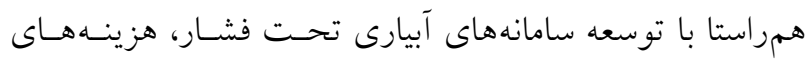

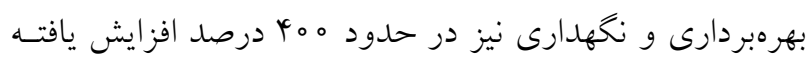

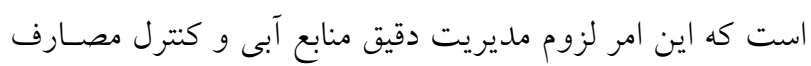

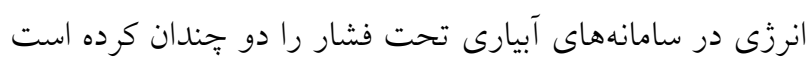

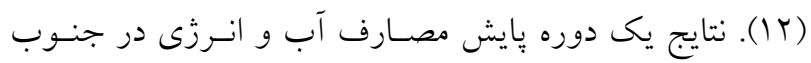

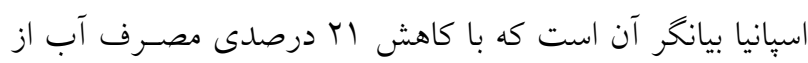

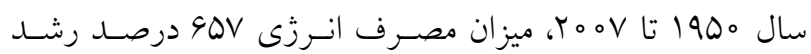

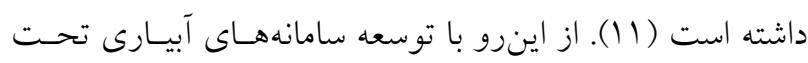

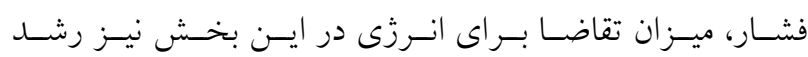

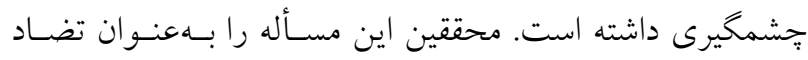

مدرنسازى سامانهاى آبيارى تحت فشار نام بردهاند (r ا I).

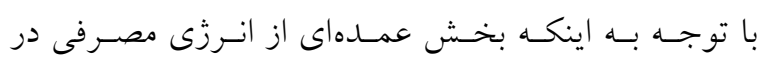

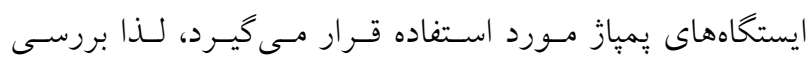

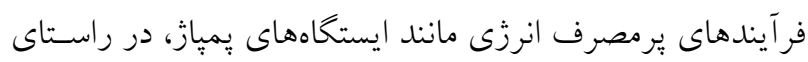

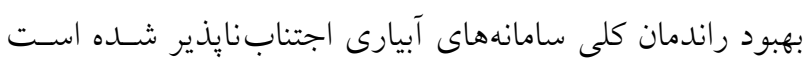

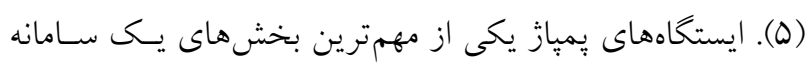

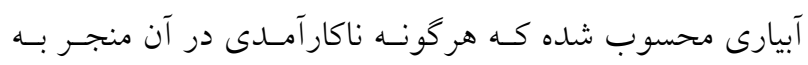

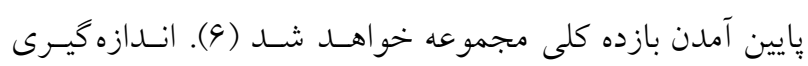

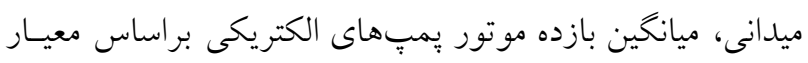

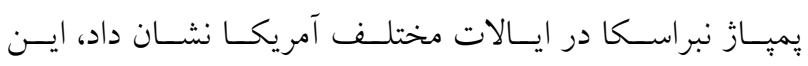

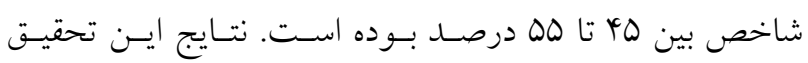

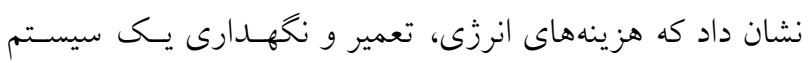

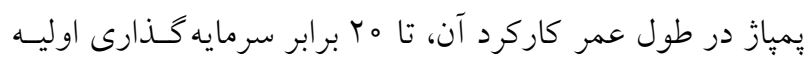




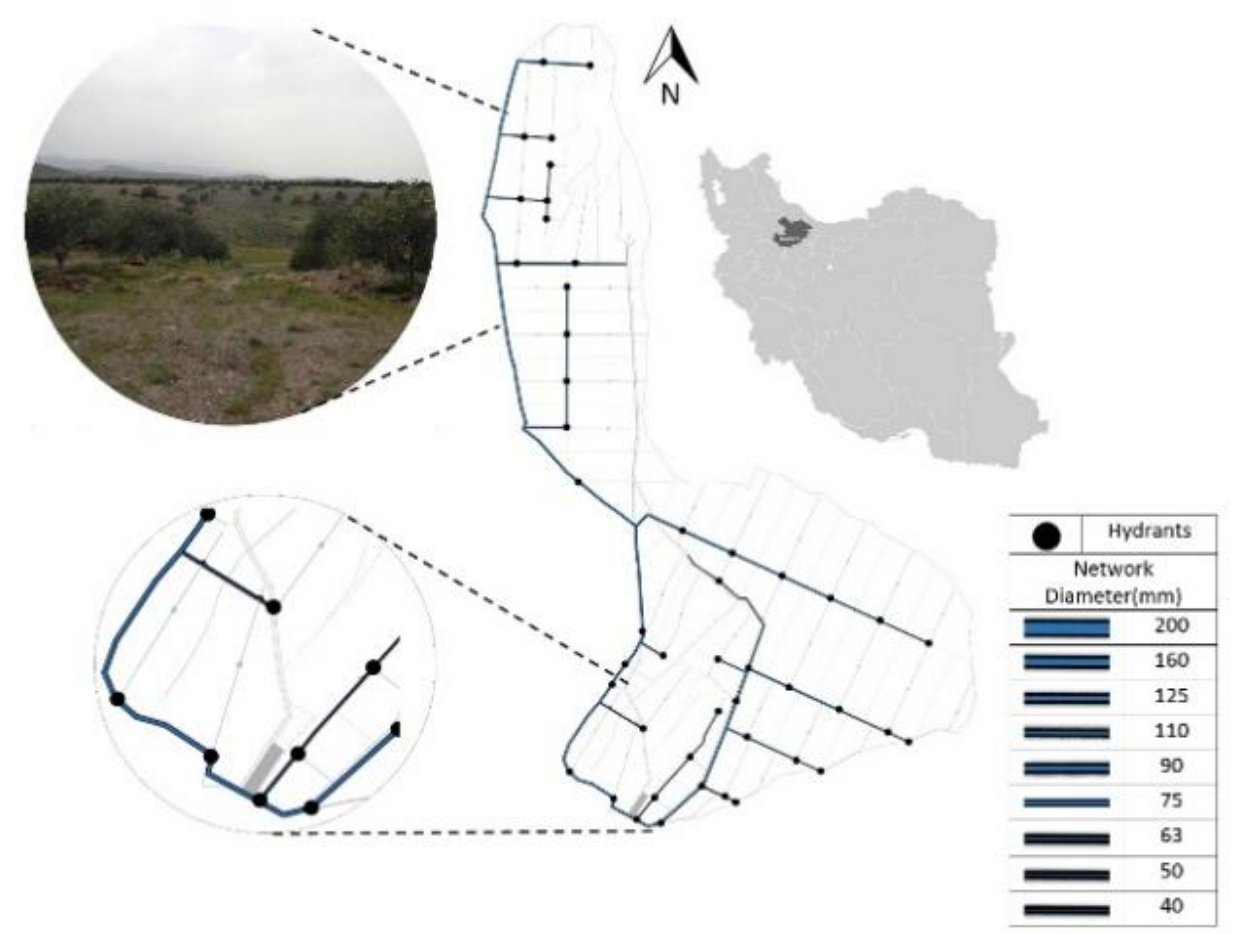

شكل 1. طرح كلى جانمايى خطوط لوله آبرسان در سامانه آبيارى مورد مطالعه

يميــاز ثانويسه بـه درون سـامانه آبيـارى اسـت. بـهدليـل شـكل

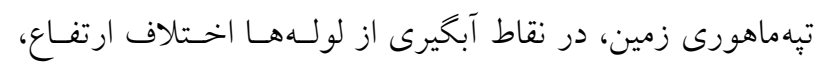

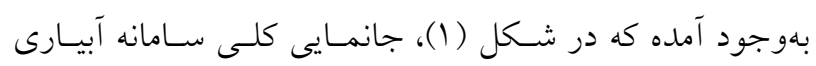

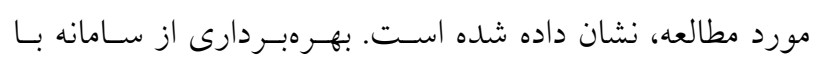

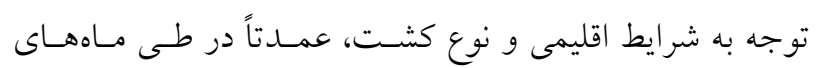
ارديبهشت تا شهريور صورت كرفته كه حداكثر و حداقل ميـزان نياز آبى (براساس سند ملى آب كشاورزى)، بـهترتيـب در دهــه سوم تيرماه و دهه سوم ارديبهشتماه بوده است. در اين راستا و با توجه به مقادير نياز آبى زيتون و تغييرات ضـريب سـايهانـداز

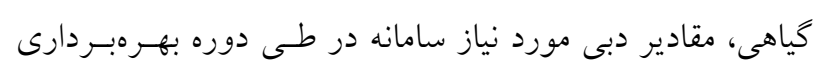
براورد شده است. در برنامهريزى بهرهبردارى از ايستخاه يمّاز براى دور آبيارى سه روزه، مدت آبيـارى هـر ناحيـه در طـى دوره بهـــبــردارى محاسبه شده و زمان كاركرد ايستخاه يمياز، براسـاس آبيـارى دو

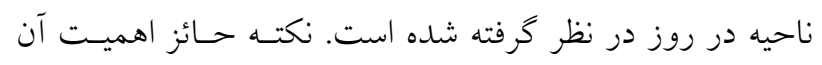

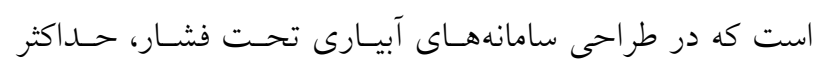
مقادير نياز آبى در كل فصل آبيارى و يا دوره بهرهبردارى، مبناى
كشاورزى، بهطور كامل نمايان نشده اسـت (r). هـــف تحقيـق

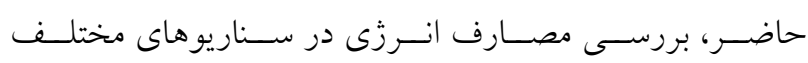
بهرهبردارى ايستخاه يمياز، در يكى سـامانه آبيـارى تحـت فشـار

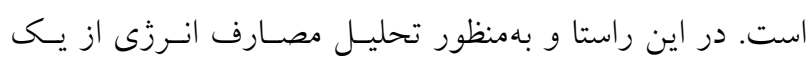

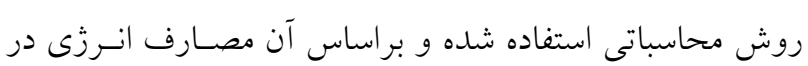
رويكردهاى مختلف بهرهبردارى از ايستخاه بميـاز مـورد تعيسين شده است، همجنين وضعيت موجود بهرهبردارى ايستخاه يمِّاز نيز براساس معيار يمياز نبراسكا مورد ارزيابى قرار كرفته است.

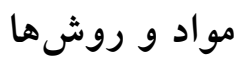

منطقه مورد مطالعه در اين تحقيق، كشـت و صسنعت اشـرفيه بـا مساحت هم هكتار است كه در بخش مركزى طارم سفلى استان قزوين قرار كرفته است. اراضى محدوده طرح عمدتاً نـاهموار و

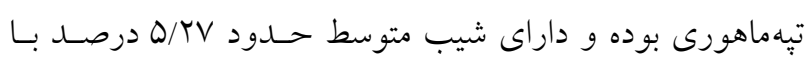
كثـت محصـول زيتـون اسـت. سيسـتم آبيـارى ايسن محسدودهه براساس روش آبيارى قطرهاى و شيوه آبخيرى اراضى، بر مبنـاى

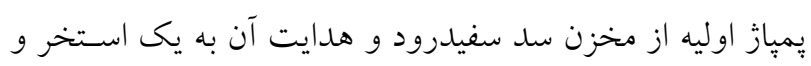


جدول ا. مقادير دبى (ليتر بر ثانيه) و فشار مورد نياز (متر) در طى دوره بهرهبردارى

\begin{tabular}{|c|c|c|c|c|c|c|c|c|c|c|c|c|}
\hline \multicolumn{2}{|c|}{ ناحيه شش } & \multicolumn{2}{|c|}{ ناحيه ينج } & \multicolumn{2}{|c|}{ ناحيه جهار } & \multicolumn{2}{|c|}{ ناحيه سه } & \multicolumn{2}{|c|}{ ناحيه دو } & \multicolumn{2}{|c|}{ ناحيه يك } & \multirow{2}{*}{ سال بهرهبردارى } \\
\hline do & دبى & هد & دبى & هد & دبى & هد & دبى & هد & دبى & هد & دبى & \\
\hline rN/q & $\mid N / r$ & $\varphi Q / 9$ & $\mid k / 4$ & $Y \wedge / V$ & $11 / \mathrm{V}$ & $\psi_{\Lambda}$ & $I T / T$ & $\varphi 0 / 9$ & $\mid k / 4$ & MN/G & $1 N / \mu$ & سال اول \\
\hline$\psi_{0}$ & $Y Y / D$ & $\varphi q / r$ & $19 / r$ & $\varphi q / 0$ & $10 / 9$ & $Y N / 9$ & 19 & $\varphi 9 / T$ & $19 / 4$ & $y_{0}$ & $M Y / D$ & سال دوم \\
\hline$|y| / \Lambda$ & $\mu \circ / 0$ & $\varphi \wedge / 4$ & ry & $\Delta \circ / 4$ & $19 / 4$ & $49 / 9$ & $r \circ / 0$ & $\forall N / 4$ & YY & $41 / \wedge$ & $r \circ / \phi$ & سال ينجم+† \\
\hline id & re/9 & $01 / 0$ & $r q / V$ & $\Delta / / q$ & $r \mu / 4$ & $\Delta V / \varphi$ & $Y Y / D$ & $01 / 0$ & $r 9 / V$ & YQ & $r 4 / 9$ & سال هشتم +†+ \\
\hline$\Delta r / q$ & $K Y / \Lambda$ & $q 4 / 0$ & MT/V & $v_{0}$ & $r V / r$ & 99 & TN/V & $94 / 0$ & 每/v & $\Delta r / q$ & $Y Y / \Lambda$ & سال دهم \\
\hline
\end{tabular}

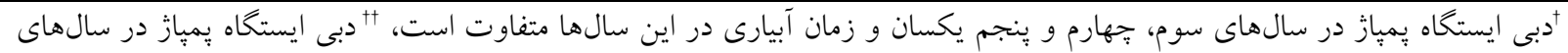

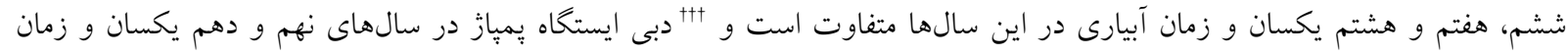

نياز سامانه در طى دوره بهرهبردارى انتخاب شده اسـت. شـكل

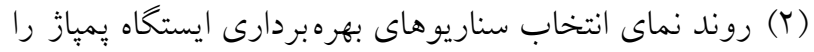

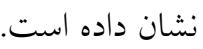
شايان ذكر است در انتخاب بِمٍ، علاوهبر نياز بهرهبـردارى

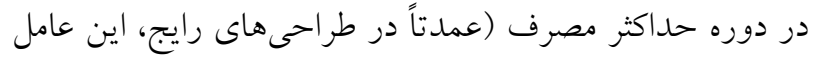

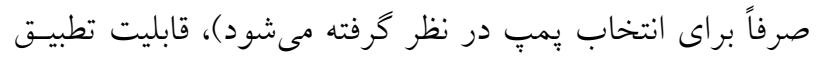

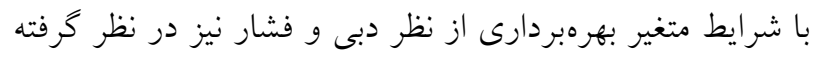

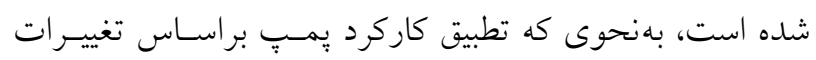

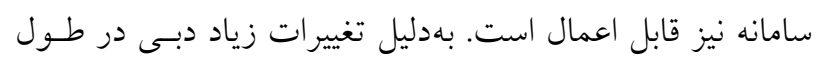

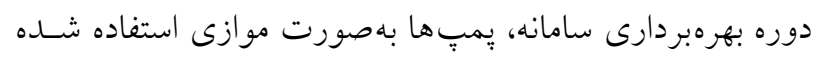

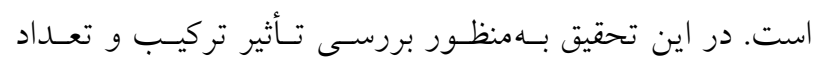

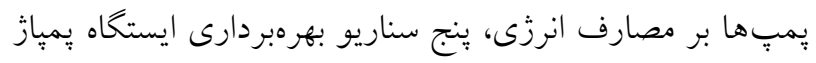

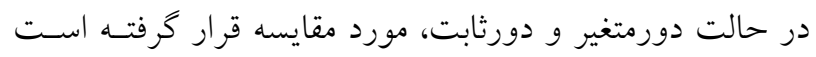

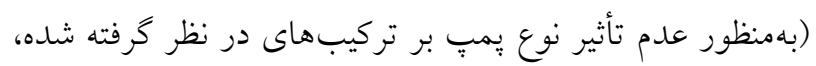

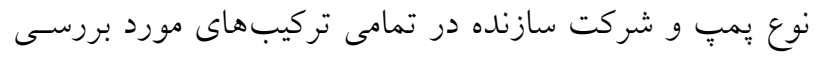

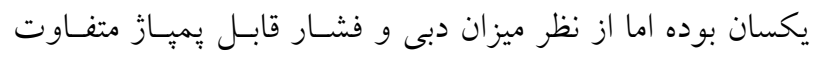
بوده است). جدول (Y) سناريوهاى مختلف بهرهبردارى ايستاه

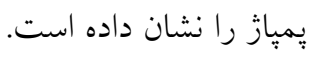
بر اين اساس بنج سناريو در مدلسازى مصـارف انـرزى در

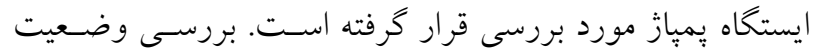
موجود ايستخاه يمياز در دو بخش انجام شده است. در كام اول
طراحى ايستخاه يمياز بوده و اصولاً منحنى مشخصه سـامانه، در طر احى ايستخاه بِمياز نقشى ندارد (1). منحنى مشخصـه سـامانه

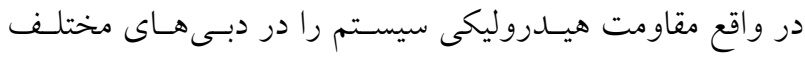
نشان داده و در بررسى ارتباط ديناميك سامانه آبيارى و عملكرد

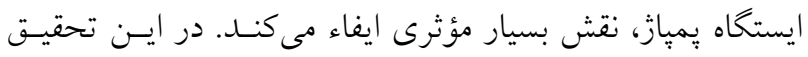

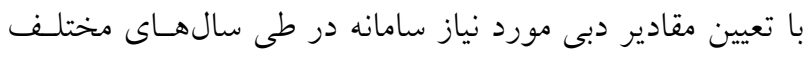

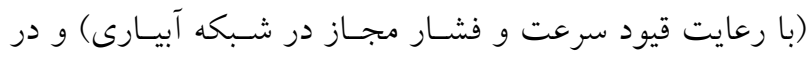

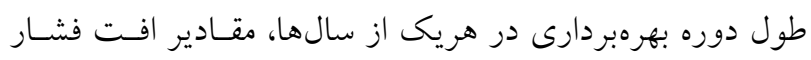

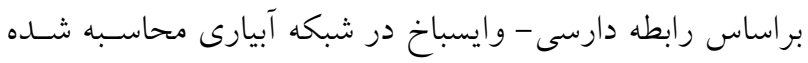

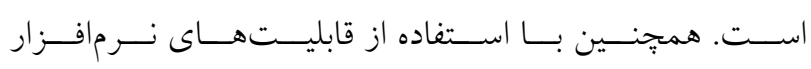
WATERGEMS

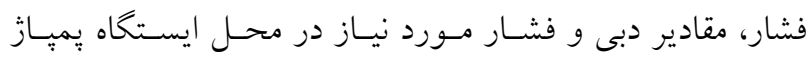

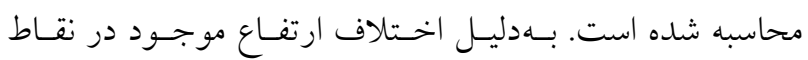
آبخيرى و مساحت اراضى تحت آبيـارى، مقـادير دبسى و فشــار مورد نياز در ناحيههاى مختلف، با هـم متفــاوت اسـت. جــدول

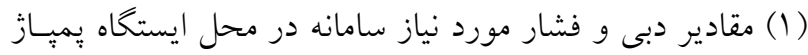
را نشان داده است.

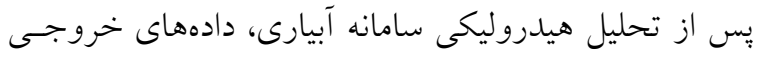
نرمافزار از طريق لينك با صفحه گسترده EXCEL، به مدل تهيه

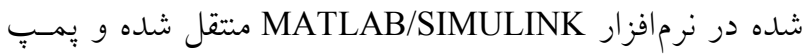

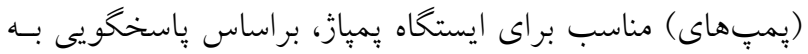




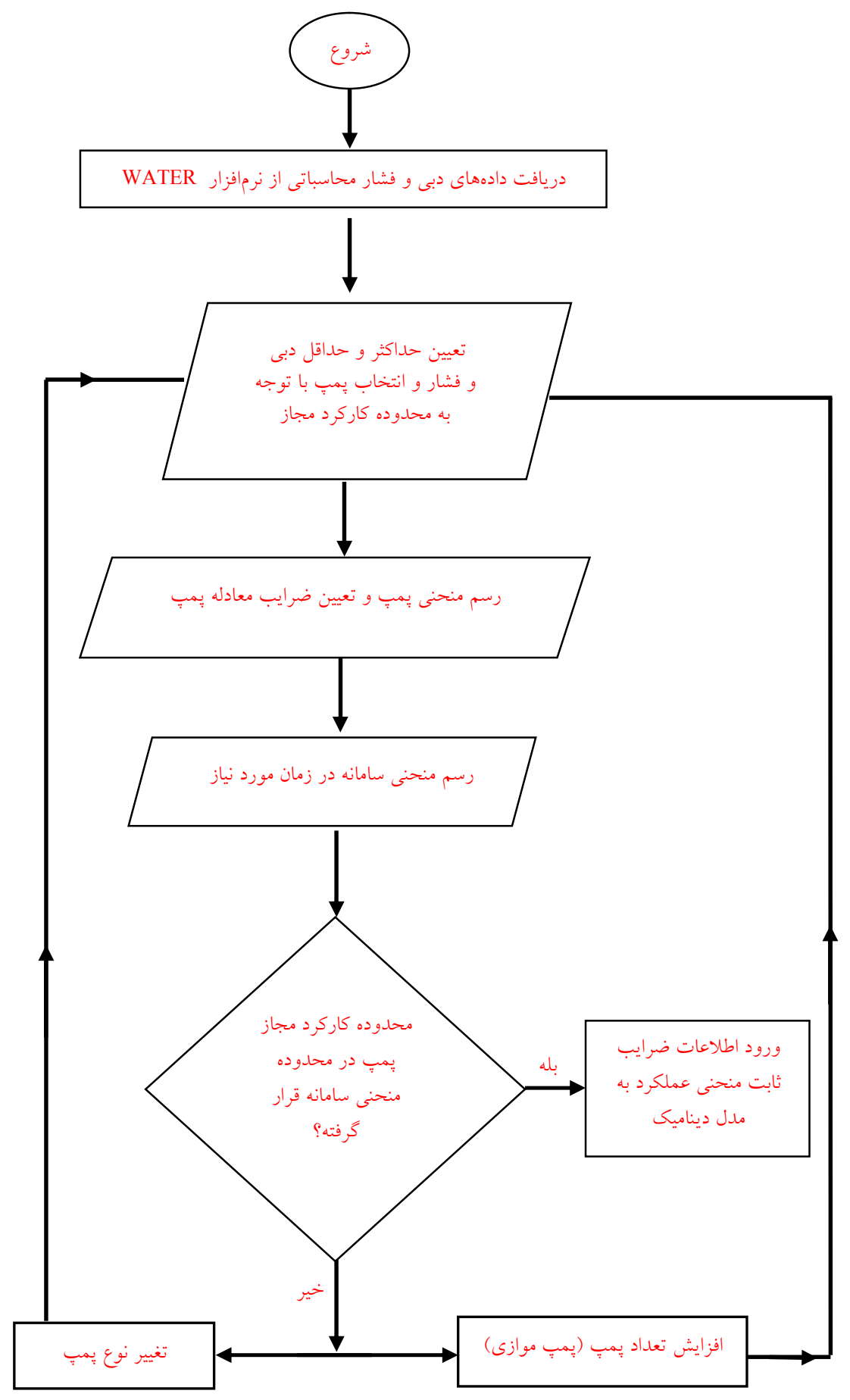

شكل r. روند نماى انتخاب سناريوهاى بهرهبردارى ايستخاه يمباز 


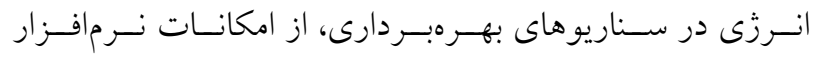
MATLAB/SIMULINK

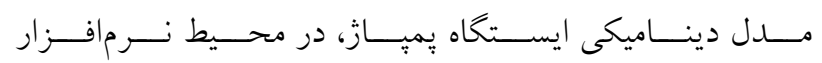
MATLAB/SIMULINK

مصارف انرزى بـا رويكـرد بـهـ بررسى اثـرات متقابـل منحنسى

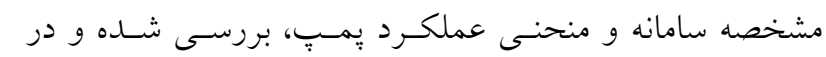

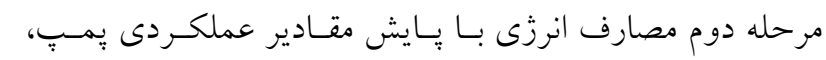

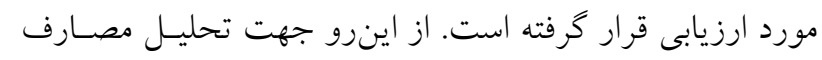
جدول r. سناريوهاى مختلف تهري

\begin{tabular}{|c|c|c|c|}
\hline روش بهرهبردارى ايستخاه يمڤاز & نوع بمب مورد استفاده & تعداد بمب & 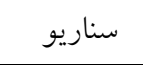 \\
\hline 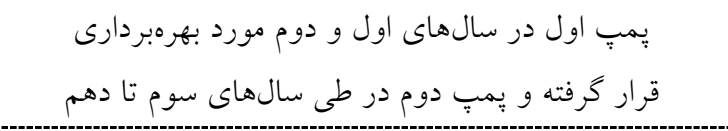 & WKL 80/5 -WKL 100/3 & r & 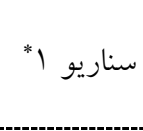 \\
\hline همانند سناريو ا ولى با يمٍ دور متغير بهرهبردارى شده است & WKL 80/5 -WKL 100/3 & r & 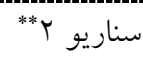 \\
\hline سال دوم تا هشتم اول در سال اول و تركيب يمٍ اول و دوم در طى سي & ETA $40-250$ & r & 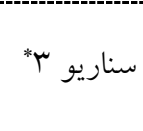 \\
\hline همانند سناريو گ ولى با يمٍ دور متغير بهرهبردارى شده است & ETA $40-250$ & r & 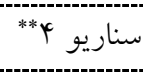 \\
\hline وضعيت موجود ايستخاه يمياز - بهرهبردارى يمٍ دور ثابت & WKL $125 / 3$ & 1 & سناريو ه \\
\hline
\end{tabular}

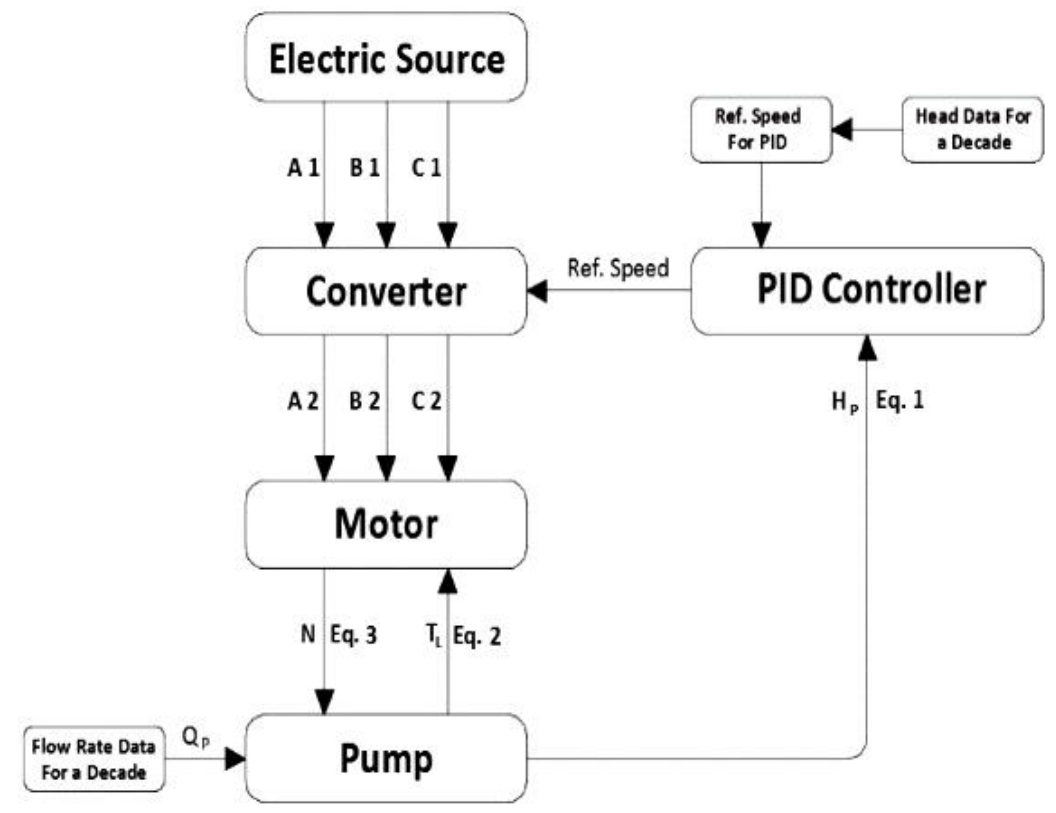

MATLAB شكل r. دياگرَام بلوكى مدل بمِّ دورمتغير در نرمافزار

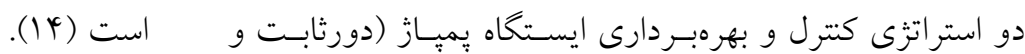
$\mathrm{H}=\mathrm{aQ} \mathrm{Q}^{r}+\mathrm{bQn}+\mathrm{cn}^{r}$

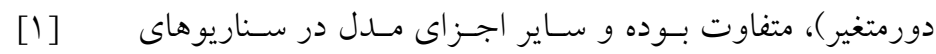

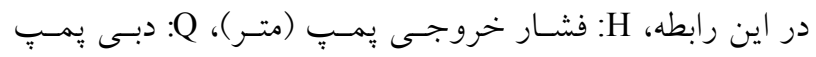
مورد بررسى ثابت است. در بخش مدل ديناميكى بمٍٍ، از رابطه (مترمكعب بر ساعت)، n: سرعت دورانس الكترويمـٍٍ (دور در (1) كه شكلى از معادله ريكاتى(Riccatti) است، اسـتفاده شــهـ 
رابطه (Y) بيانكر نحوه محاسبه گشتاور بار با استفاده از مدل

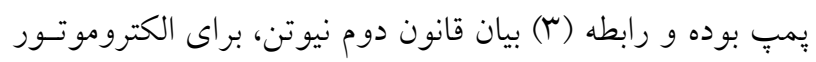

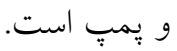

$\mathrm{T}_{\mathrm{L}}=\mathrm{T}_{\text {friction }}+\mathrm{T}_{\mathrm{P}}=\mathrm{B} \cdot \mathrm{n}+\mathrm{T}_{\mathrm{P}}$

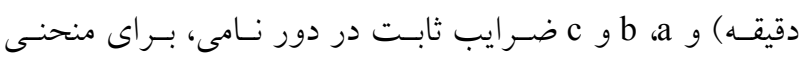

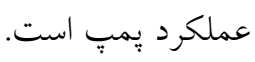
اين ضرايب براى بمبِهاى انتخابى در جدول (r) محاسبه شده است.

جدول r. مشخصات ضرايب منحنى عملكرد يُمٍ

\begin{tabular}{|c|c|c|c|c|c|}
\hline \multicolumn{3}{|c|}{ ضر ايب ثابت منحنى عملكرد پِمبِ } & \multirow{2}{*}{ دور نامى (دور در دقيقه) } & \multirow{2}{*}{ قدرت (كيلووات) } & \multirow{2}{*}{ مدل الكترويمبٍ } \\
\hline $\mathrm{c}$ & $\mathrm{b}$ & $\mathrm{a}$ & & & \\
\hline Y/TYE- & $-V / \circ 9 E-\varnothing$ & $-0 / 004 \wedge$ & 1000 & rt & WKL $80 / 5$ \\
\hline$r / 94 \mathrm{E}-0$ & $-9 / \mu \Gamma E-V$ & $-0 / 0014$ & 1000 & rv & WKL 100/3 \\
\hline$\Delta / q \circ E-\Delta$ & $-r / \circ \mid E-\omega$ & $-0 / 0000$ & 1000 & 9. & WKL 125/3 \\
\hline$N / Y \varphi \mathrm{E}-\varphi$ & 010001919 & $-0 / 01 \wedge 9$ & roo & $1 N / 0$ & ETA40-250 \\
\hline
\end{tabular}

بهرهبردارى خواهد شد. درايوها با ايجاد تغيير فركـانس ورودى

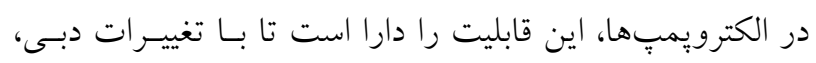

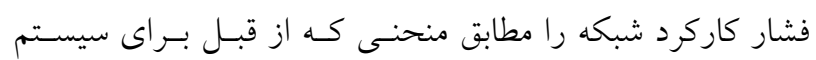
تعريف شده است، تغيير دهد.

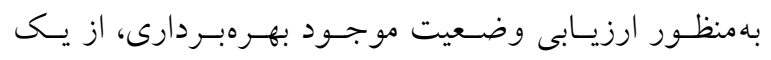

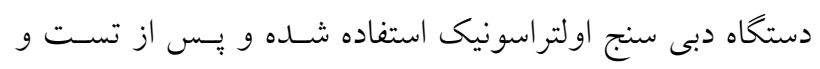

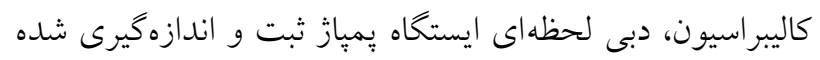

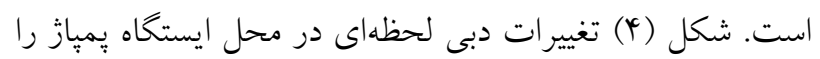
نشان داده است. همجنين فشار خروجى در محل ايستخاه كتترل

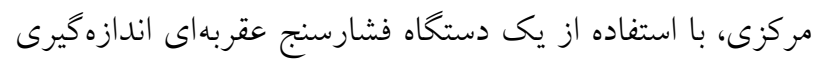

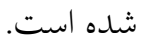
بهمنظور محاسـبه و ارزيـابى مصـارف انـرزى در وضـعيت

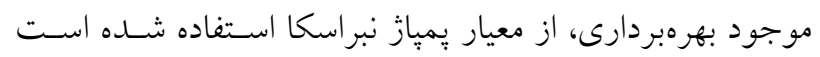

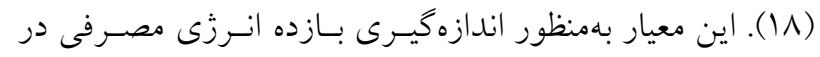

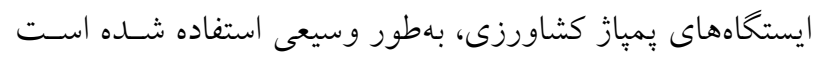

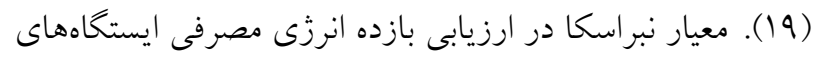

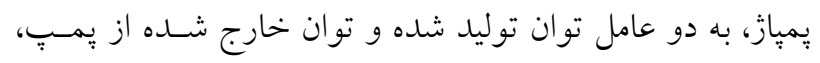

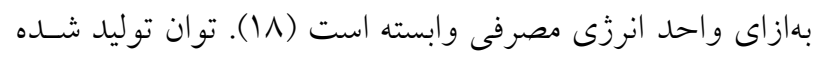

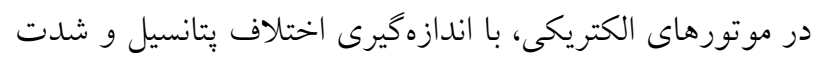
جريان الكتريكى، براساس رابطه (Y) محاسبه شده است. $P i=r \times V \times I \times \cos \varphi$

$$
\mathrm{T}_{\mathrm{e}}-\mathrm{T}_{\mathrm{L}}=\mathrm{I}\left(\pi / \mathrm{r}_{\circ}\right)(\mathrm{dn} / \mathrm{dt})
$$

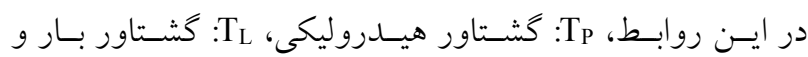

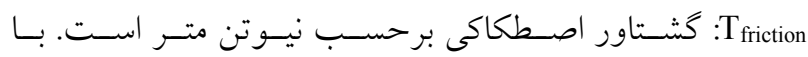

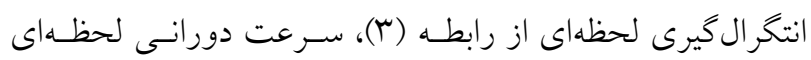

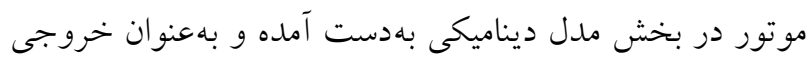

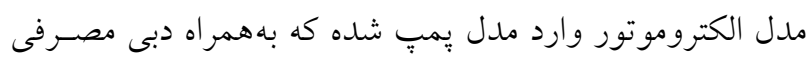

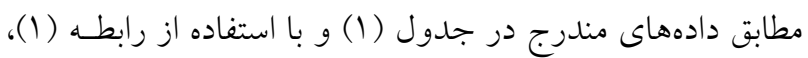

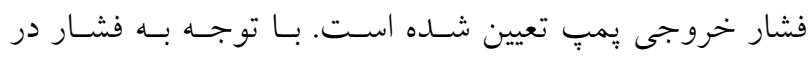

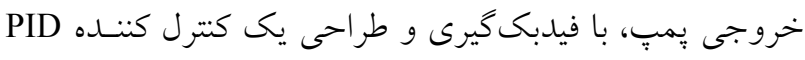

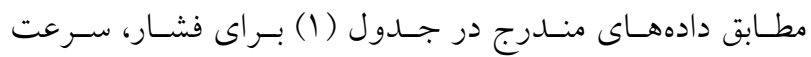
دورانى محاسبه شده اسـت. در تعيسين سـرعت دورانسى بمسِّ،

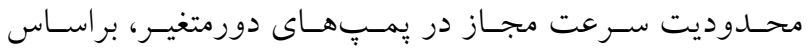

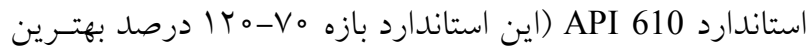

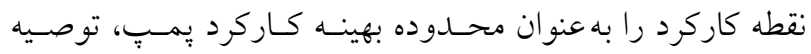

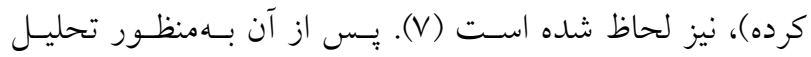
مصارف انرزى در يمّب دورمتغير از قوانين تشابه اسـتفاده شــده

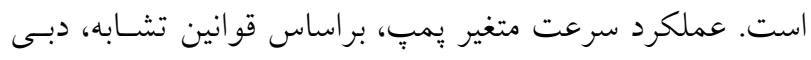

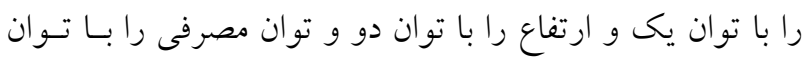

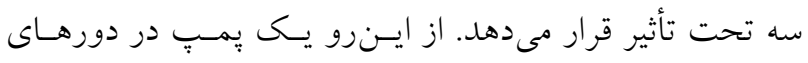

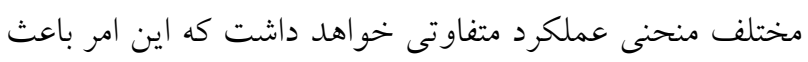

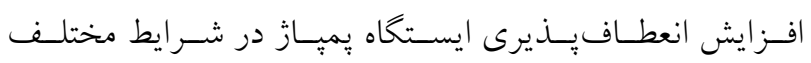




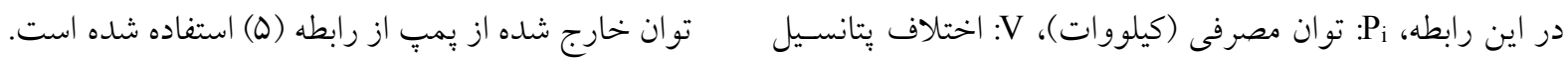
$\mathrm{P}_{\text {out }}=(\mathrm{Q} \times \mathrm{H}) / \mathrm{\circ} \cdot \mathrm{r}$

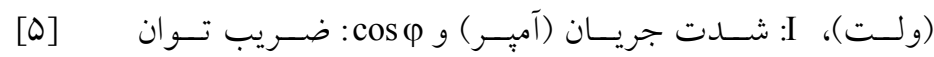

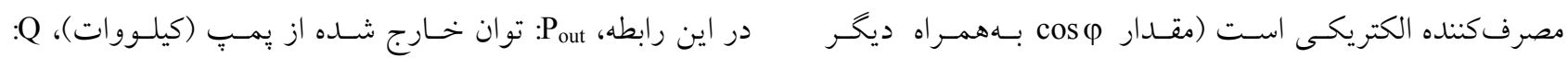

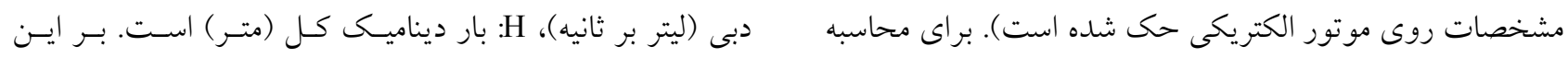

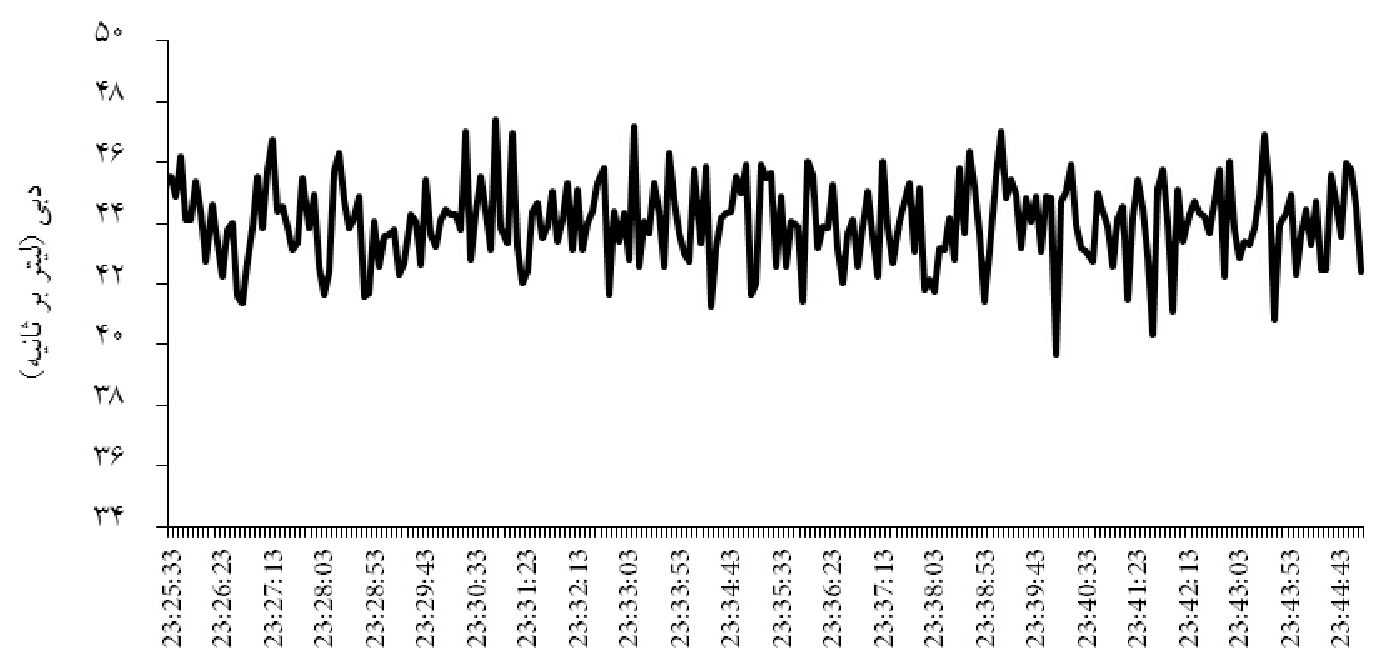

زمان (ثانيه)

شكل f. تغييرات دبى لحظهاى در ايستخاه پِمِاز

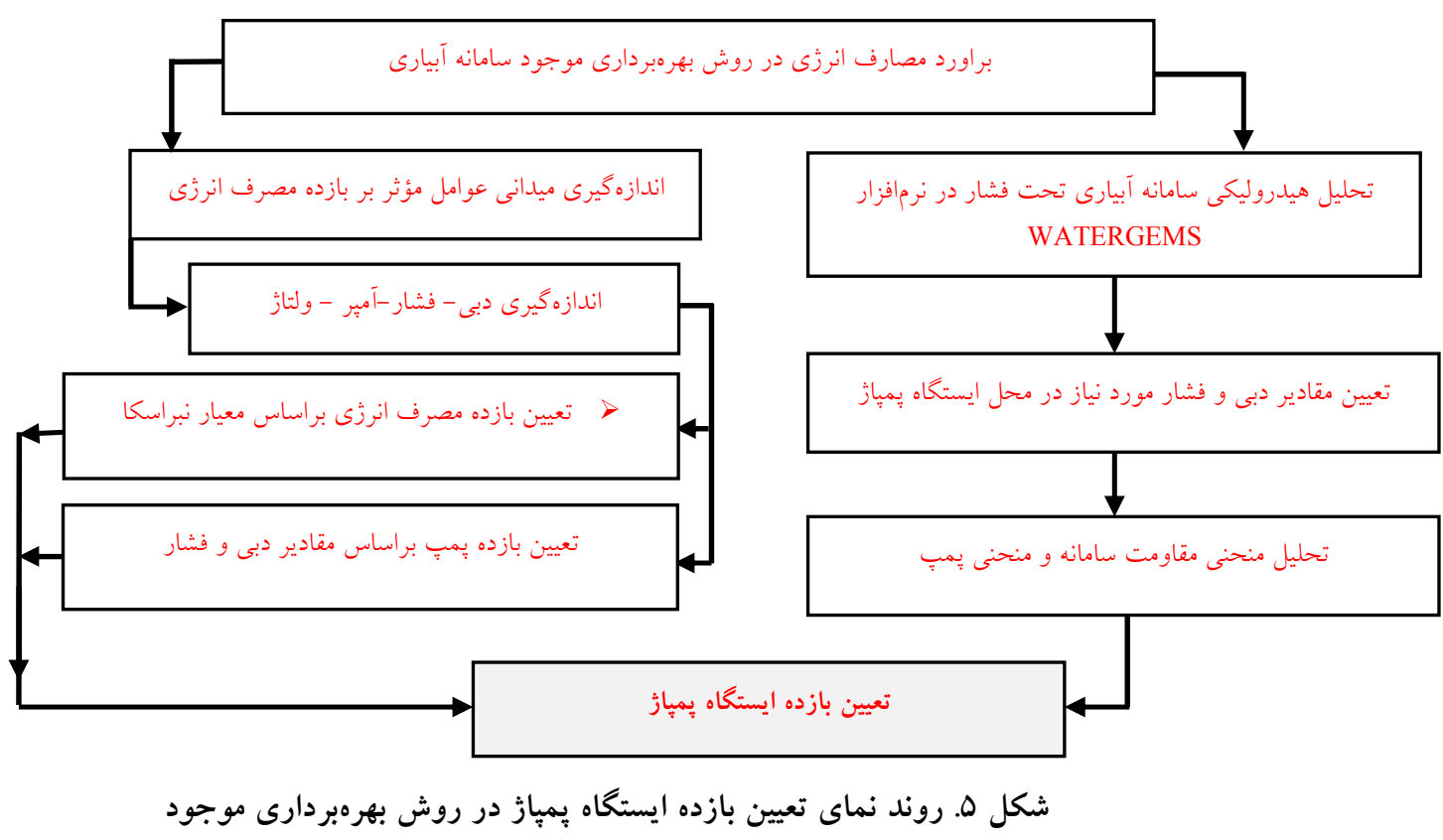

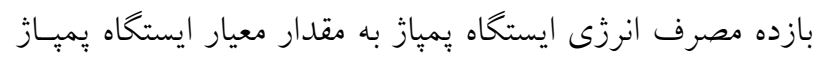

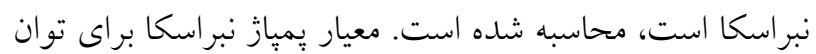
موتور الكتريكى بهازاى واحد انرزى مصرفى MM/ه (اسب بخـار

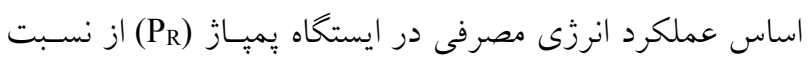

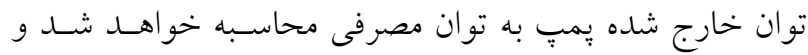

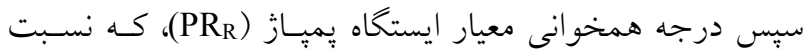




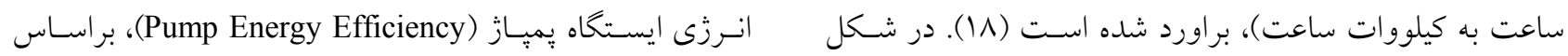
رابطه (9) محاسبه شده است (I)).

(ه) روند نماى تعيين بازده مصرف انرزى، در روش بهرهبردارى $\mathrm{PEE}=\circ / r V T \Delta \times\left(\sum \mathrm{V}_{\mathrm{i}} \mathrm{H}_{\mathrm{i}}\right) / \sum \mathrm{E}_{\mathrm{i}}$ ايستخاه بِمياز نشان داده شده است. در نهايت به منظور بررسسى ارتبـاط بـين انـرزى مصـرفى و حجم آب يمياز شده در سناريوهاى مورد بررسى، شاخص بازده

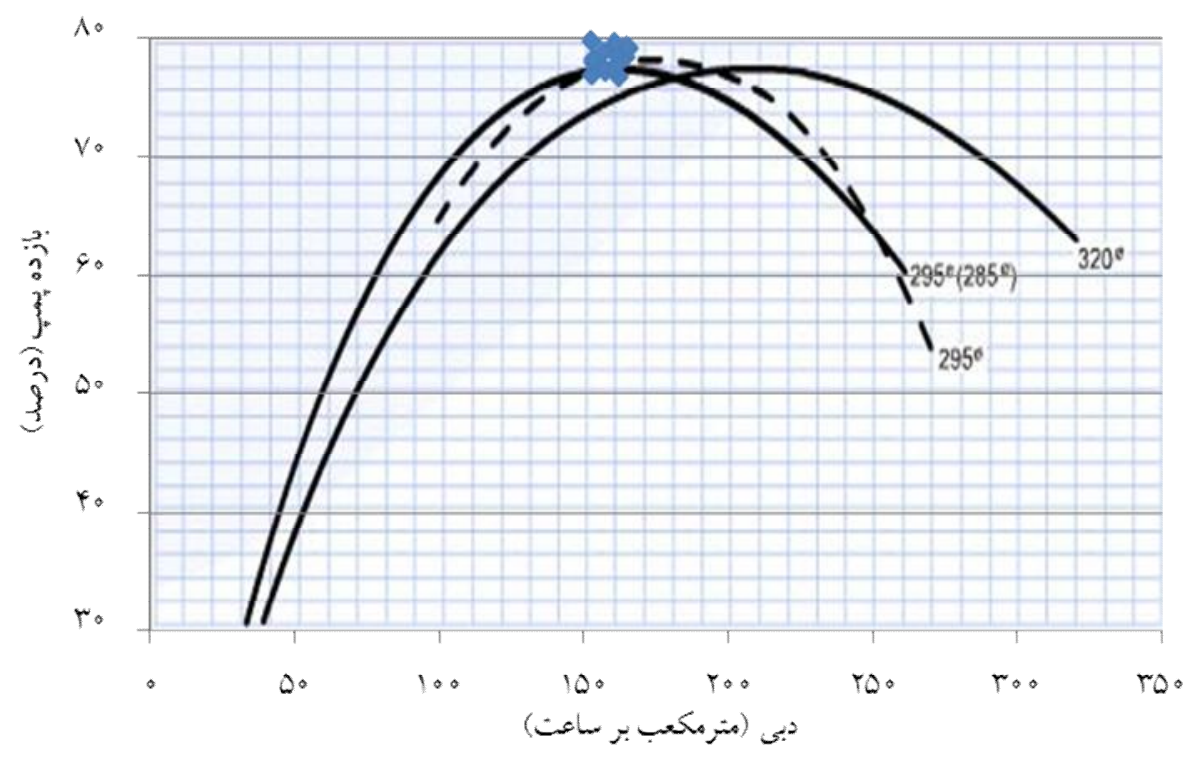

شكل 9. منحنى عملكرد يمبٍ و مقادير دبى پايش شده

و آمير برق مصرفى اندازهگيرى شـده اسـت. بررسسى وضـعيت

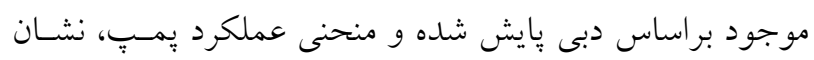
دهنده آن است كه يمٍٍ موجود (WKL125/3)، در بهترين نقطه

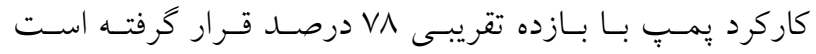

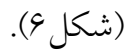

تغييرات دبى ثبت شـده در محسل خروجسى ايســاه بمِيـاز نشان داد، ميانگين دبى در محل خروجى ايستخاه يمياز لها ليتـر

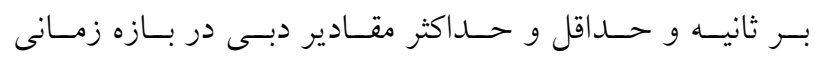

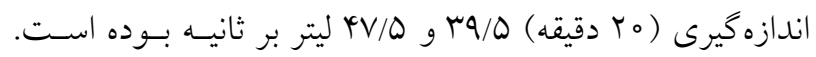
بهعبارتى در مدت زمان اندازهذيرى حدود مب درصد نوسان در مقادير دبى بمياز شده، وجود داشته است كه با توجـهـ بـه نحسوه آبخيرى ايستخاه يمهاز (آبخيرى از استخر ذخيره آب)، در حالـت ايدهآل، تغييرات دبى در زمان بايد نزديك به صفر باشد. لذا اين ميزان تغييرات دبى در محل ايستخاه يمياز، نشـان دهنـده اتــرات
در ايسـن رابطـه، PEE: شـاخص بــازده انـرزى ايسـتخاه يميــاز (درصد)،V: حجم آب بمياز شده (مترمكعب)، H: فشـار توليـد

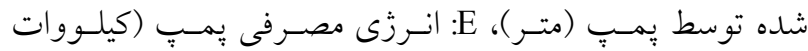
ساعت) و i دوره زمانى بهرهبردارى ايستخاه بمياز است.

نتايج و بحث وضعيت موجود بهرهبردارى ايستخاه يمباز در دو بخـش، مـورد بررسى قرار گرفتـه اسـت. در بخـش اول بـازده كلى مصـارف انرزى، براساس يايش يار امترهاى بهـرهبـردارى برحسـب معيـار يمياز نبراسكا محاسبه شده است. در بخـش دوم اثـرات متقابـل منحنى عملكرد يُمٍٍ و منحنسى مشخصـه سـامانه، بـر مصـارف

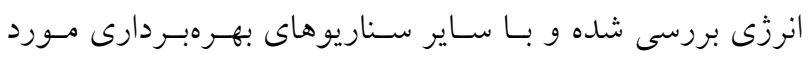

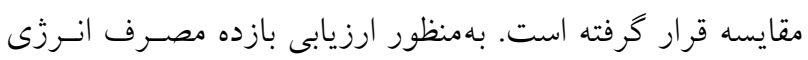
در وضعيت موجود بهرهبردارى، مقادير دبى، فشار، ولتاز جريـان 
زيادى داشته، بهطورى كه فشـار ثبـت شــده در محـل خروجـى

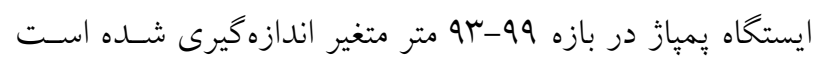
درصورتى كه حداكثر فشار مورد نياز در طـى دوره بهـــبـــــارى Vo متر بوده است. با توجه بـه مقـادير ثبـت شـده دبسى، فشـار، شدت جريان (آمير) و ولتـاز بـرق مصـرفى، وضـعيت موجـود

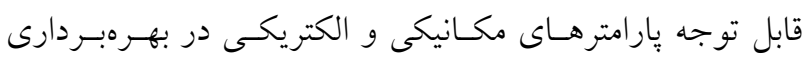

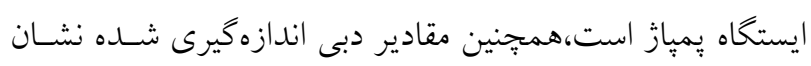
داد، ميزان دبى يمّاز شده يــنج تـا هفـت درصــ، بـيش از نيـاز

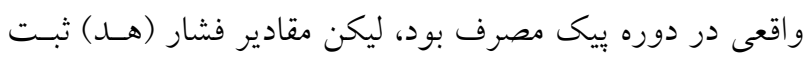
شده در محل ايستخاه بمياز، با فشار مورد نياز سـامانه اخـتلاف

جدول f. محاسبه بازده ايستخاه يمياز براساس معيار نبراسكا

\begin{tabular}{|c|c|c|c|}
\hline$\circ / \wedge \Delta$ & $\cos \varphi$ & 40 & دبى (ليتر بر ثانيه) \\
\hline$\Lambda \Delta / r$ & توان ورودى (كيلووات) & 190 & شدت جريان (آمير) \\
\hline ky & توان خروجى (كيلووات) & ro. & ولت ازت (ولت) \\
\hline$\circ / \mathrm{VA}$ & درجه عملكرد نسبت به معيار نبراسكا & щ人。 & ولتاز نامى (ولت) \\
\hline Or & بازده كل (درصد) & 99 & ارتفاع ديناميكى (متر) \\
\hline
\end{tabular}

بهرهبردارى از ايستخاه يمياز، نشان دهنــه آن اسـت كـه مقـادير فشار اضافى جريان در محل ايستخاه بمرياز كه بهدليل عدم تطابق منحنى مشخصه سامانه، منحنى بمبٍ و انتخاب ناصسحيح بمــ" در ايستخاه يمياز بوده، يكى از مهمترين عوامل تلفات انرزى در اين روش بهرهبردارى است، بهطورىكـه در وضـعيت موجـود، عليرغم بمياز دبى يكسان با سناريوهاى ديخر، مصـارف انـرزى بيش از هو درصد نسبت به ساير روشهاى بهرهبردارى افزايش يافته است. شكل (V) تغييرات شاخص بـازده مصـرف انـرزى ايســاه يمياز (PEE) در سناريوهاى مختلف بهرهبردارى سامانه را نشان داده است. اين شاخص در وضـعيت موجــود ايسـتخاه يميـاز و براساس مقادير هد فشارى يمٌٍ، حجم آب بِمياز شده و ميـزان انرزى مصرفى، צY تا م Y درصد بـوده اسـت. بـهـبـارتى بـازده

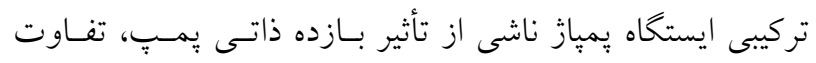
توان خروجى و ورودى به يمبِ و تأثير منحنى مقاومت سامانه، در وضعيت موجود بهرهبردارى ايستخاه يمياز كمتر از || درصد بوده است. اين در حالى است كه ميانخين بازده مصـرف انـرزى ايستخاه يمياز (PEE) در سناريوهاى يـك، دو، سـه و جههـار (در

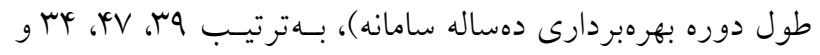
الا درصد بوده است. بهعبارتى انتخاب صحيح يمبٍ كه متناسب با تغييرات منحنى مقاومت سامانه (صـرف نظـر از تـأثير عوامـل
بهرهبردارى براساس معيار نبراسكا ارزيابى شد كـه بـه نتـايج آن در جدول (Y) اشاره شده است. بهعبارتى بازده ايستخاه يمِّاز؛، متأثر از بازده ذاتى يُمٍ و بازده مصرف انرزى (متأثر از تفـاوت توان ورودى و خروجى به يمبٍ) بهترتيب VA و له درصد بوده

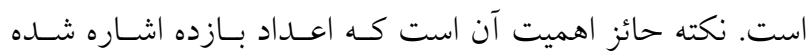
صرفاً مرتبط با شرايط بهرهبردارى بوده و نشانكر يتانسيل تلفات انرزى، بهدليل عدم تطابق منحنى بِمٍٍ و منحنى سـامانه نيسـت. در كام سوم جهت تعيين بازده مصـرف انـرزى (بـازده متـأثر از منحنى مقاومت سامانه و منحنسى عملكـرد پِمــبِ)، در وضـعيت موجود بهرهبردارى و ساير سناريوهاى مورد بررسى از قابليـت هاى مدل ديناميكى استفاده شده است. با توجه به آنكه مصارف انرزى در بمِّهاى دورمتغير، براساس تغيير دور متفاوت است، بر اين اساس ابتـدا مقــادير محاسـباتى دور يمــب در طـى دوره بهرهبردارى تعيين شده كه به نتايج آن در جدول (ه) اشاره شده جـــدول (9) انـــرزى مصـــرفى در ســناريوهاى مختلـــف بهرهبردارى از ايستخاه يمياز براساس نتايج خروجى مـدل نشـان داده اســت. نتــايج تحليلـى انــرزى مصــــى در يـــى دوره بهرهبردارى دهساله سامانه، نشان دهنده آن است كه ميزان انرزى مصرفى در روش بهرهبردارى با سيستم كنترل دورمتغير، كمتر از ساير روشهاى بهرهبردارى بوده است. بررسى وضعيت موجــود 


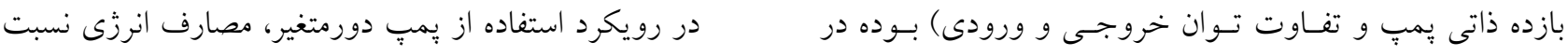

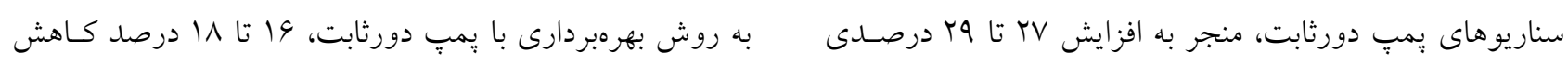

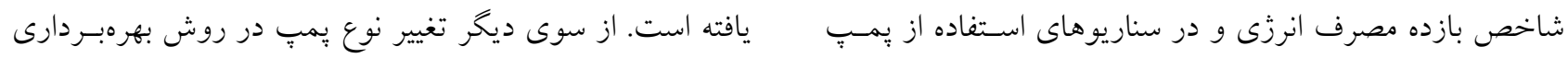

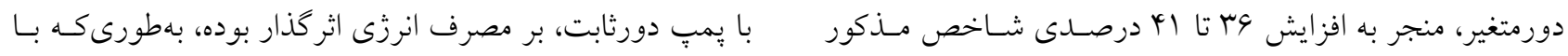

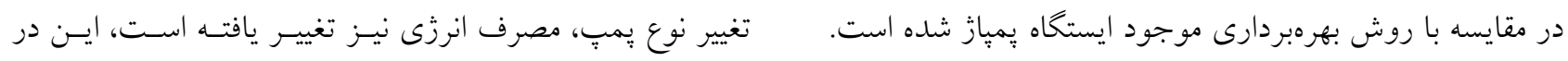

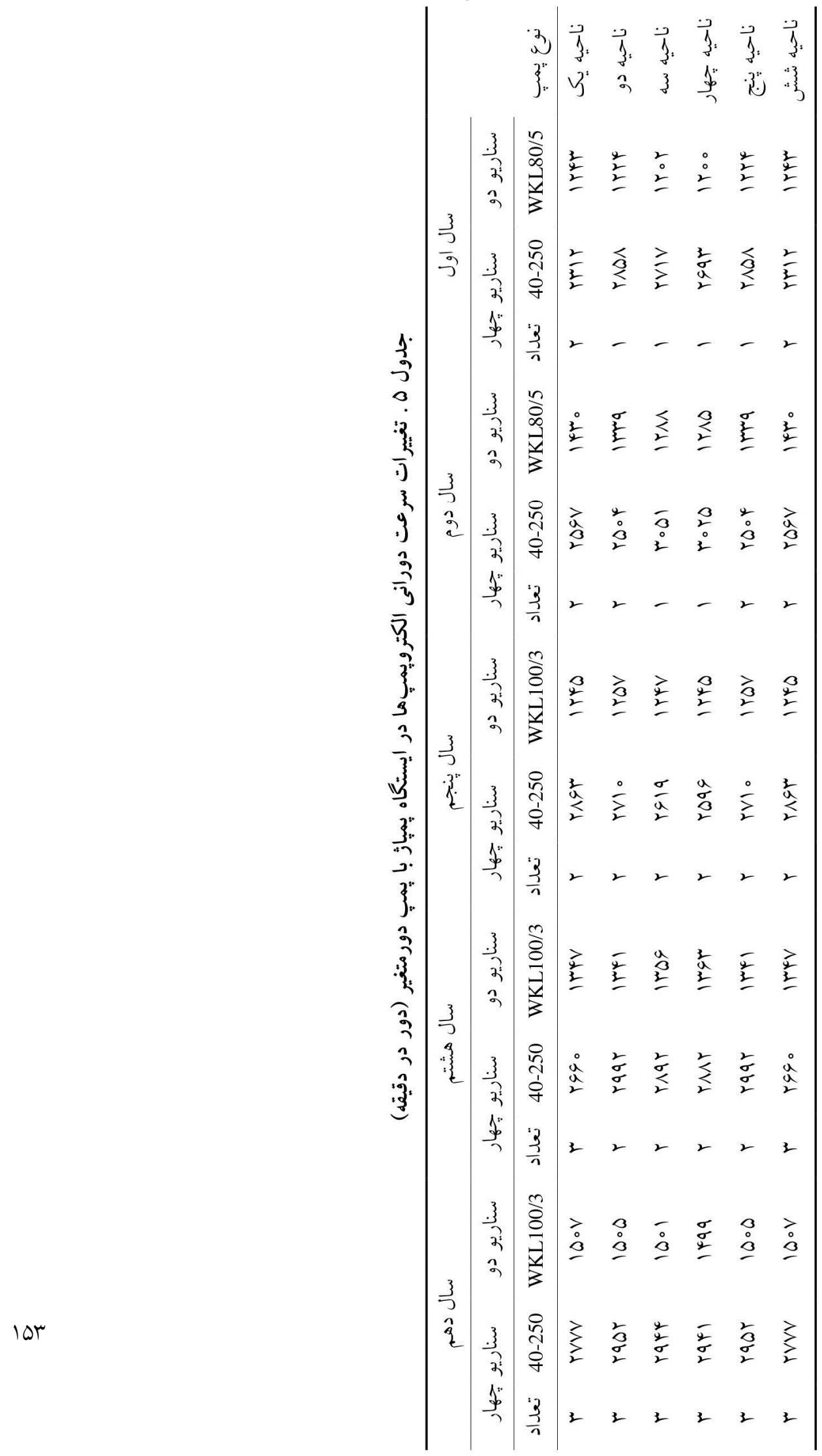


جدول 9 ـ انرزى مصرفى در سناريوهاى مختلف بهرهبردارى از ايستخاه بِمباز

\begin{tabular}{|c|c|c|c|c|c|c|c|}
\hline \multicolumn{5}{|c|}{ انرزى مصرفى (كيلووات ساعت) } & \multirow{2}{*}{ حجم آب يمبازٌ شده } & \multirow{2}{*}{ زمان كاركرد بمِب } & \multirow{2}{*}{ بهرهبردارى سال } \\
\hline سناريو ينج & سناريو جهار & سناريو سه & سناريو دو & سناريو يك & & & \\
\hline $1 V 9 \mid 00$ & rT०M & ra八lo & requg & YrVA。 & 10M194 & 1990 & سال اول \\
\hline 190900 & FEqVT & 91010 & $M T \circ \circ \Lambda$ & Y०ケ人。 & $\mid$ TVIN| & $1 \wedge Y_{0}$ & سال دوم \\
\hline $100 V 00$ & YVoGT & 94010 & $94 \wedge 9_{0}$ & 94010 & $14 M \wedge 49$ & $1 V \pi 。$ & سال سوم \\
\hline IVTA०。 & DYTHO & Vloto & $V \circ q \circ V$ & Vloto & $19019 \mathrm{~V}$ & $19 Y^{\circ}$ & سال ججهارم \\
\hline INTQY。 & $\Delta \Delta 19 \Lambda$ & VD०rG & $\vee F \wedge ৭ q$ & VQOHG & IVFYAq & $Y \circ Y \Lambda$ & سال ينجم \\
\hline $190 Y \circ 0$ & $\Delta \wedge \Lambda \wedge \vee$ & $90 \wedge 9^{\circ}$ & $Y \circ 9 M$ & $90 \wedge 9^{\circ}$ & $190 \% 11$ & $I V \wedge 。$ & سال ششم \\
\hline $1 V 0100$ & GTORS & $999 r^{\circ}$ & MrYOT & $999 r^{\circ}$ & $r \circ Y \circ V q$ & 1190 & سال هفتم \\
\hline $1 V \Delta 000$ & 94011 & VYlOo & reOVE & VYIOO & roNkar & $190^{\circ}$ & سال هشتم \\
\hline $190 Y \circ 0$ & 94149 & 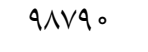 & 99494 & $90 \wedge 9^{\circ}$ & rIOMMY & IVA。 & سال نهم \\
\hline 190900 & QVYTr & aVTrT & GNVMT & 91010 & THMIGK & $1 \wedge Y_{0}$ & سال دهم \\
\hline $19 \Lambda V H T \circ$ & $90 \wedge \wedge 09$ & $V 19 . r 4$ & Drarre & GMGTYG & IVOMMIA & & جمع \\
\hline
\end{tabular}

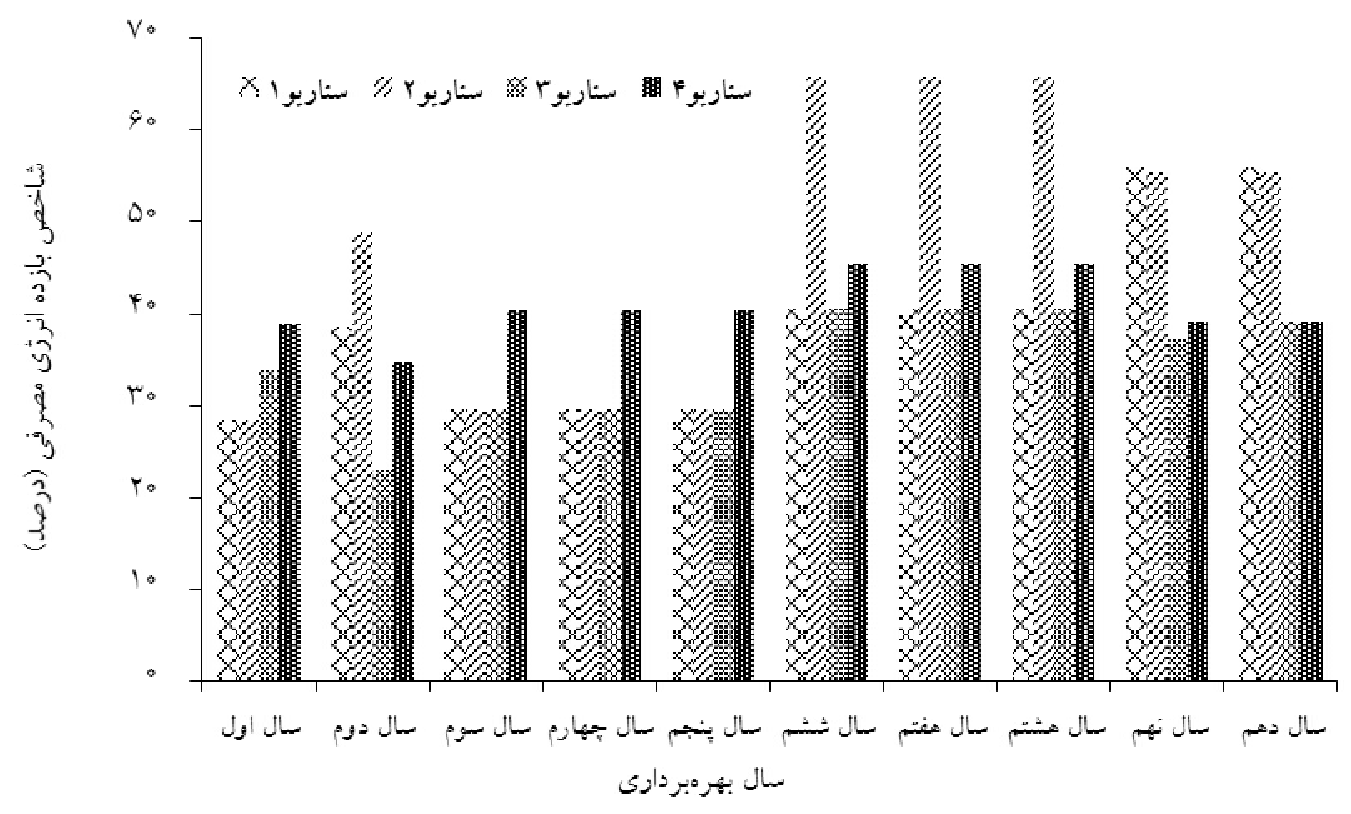

شكل V. تغييرات شاخص بازده انرزى ايستخاه يُمباز در سناريوهاى مختلف بهرهبردارى

سامانه آبيارى تحت فشار در اسيانيا 4/4 درصد (N) و در ي-نسج

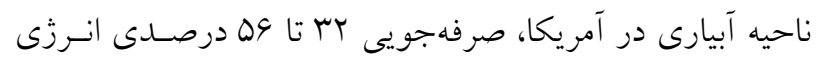

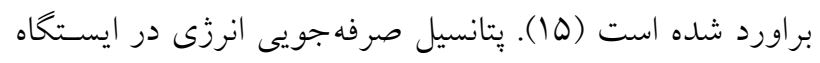

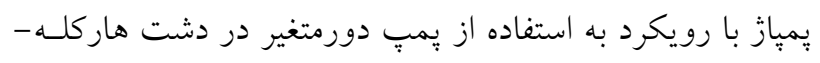

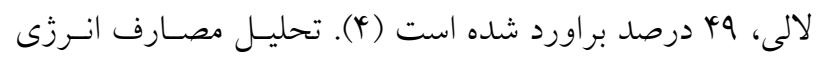

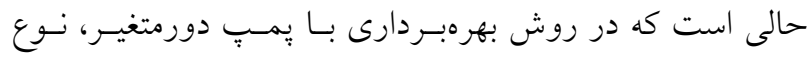

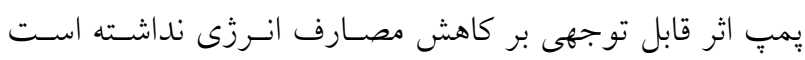

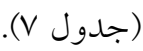

در مقايسه نتايج تحقيقات انجام شده، صرفهجويى در ميـزان

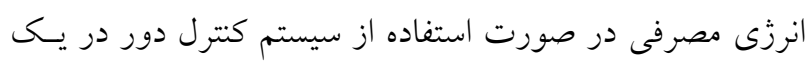


جدول V . درصد ذخيره انرزى در سناريوهاى مختلف بهرهبردارى از ايستخاه بِمياز

\begin{tabular}{|c|c|c|c|c|c|c|}
\hline سناريو ينج & سناريو جهار & سناريو سه & سناريو دو & سناريو يك & (كيلووات ساعت) & \\
\hline$-9 Y$ & t & $-1 Y$ & 19 & $*$ & GMGTYG & سناريو يك \\
\hline$-9 V$ & -10 & $-Y_{Y}$ & $*$ & -19 & DFATYG & سناريو دو \\
\hline$-\Delta V$ & 11 & * & YY & ir & V19०rk & سناريو سه \\
\hline-94 & $*$ & -11 & 10 & $-x$ & $9 \circ \wedge 109$ & سناريو جهار \\
\hline$*$ & G4 & $\Delta V$ & $9 V$ & GY & IGNVTY。 & سناريو ينج \\
\hline
\end{tabular}

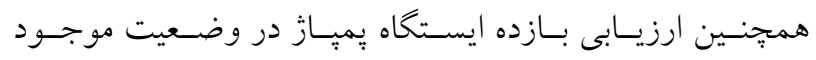

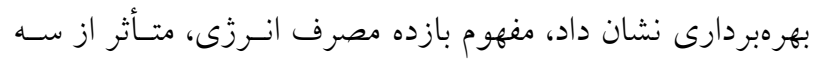

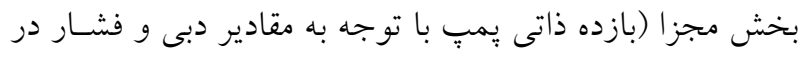

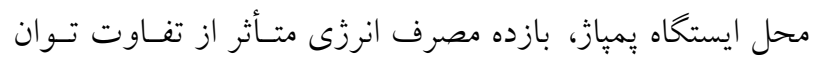

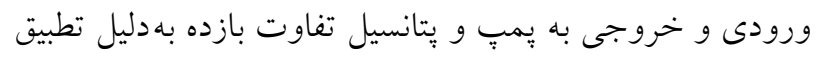

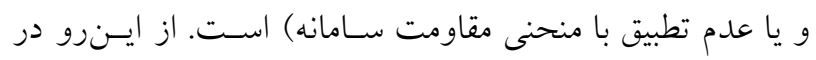

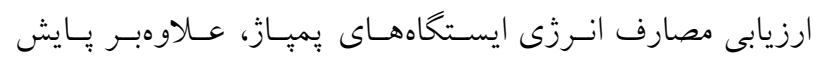

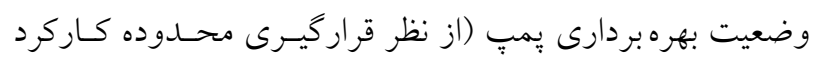

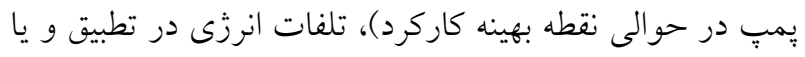

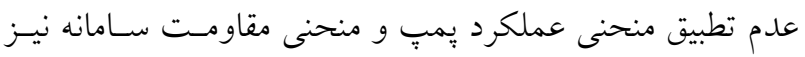
بايد در نظر كرفته شود تا بتوان يُانسيل صرفه جويى در مصارف انرزى را نيز براورد كرد. در تحقيـق حاضسر، انتخـاب ناصسحيح يمٍ مقادير قابل توجهى از تلفات انرزى در سامانه را به همـراه

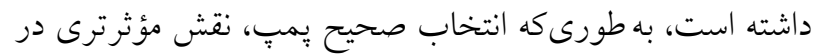
كاهش تلفات انرزى در مقايسـه بـا استفاده از يمــِ دورمتغيـر داشته است، همجينين بررسى رفتار مصارف انـرزى در ايستخاه

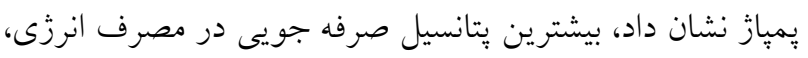

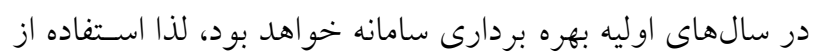

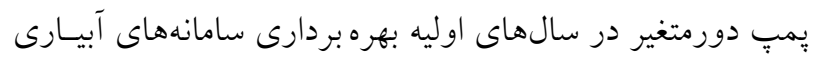

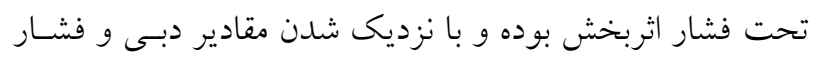

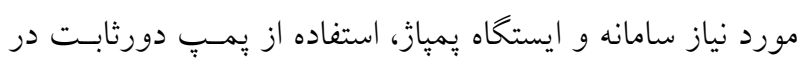
اولويت قرار مى گيرد.
در رويكردهاى مختلف بهرهبردارى از يك سامانه آبيارى تحـت فشار در جنوب ايتاليا، نشان داد صرفهجويى در مصارف انـرزى تا 49 درصد امكانيذير است (19).

\section{نتيجه گيرى}

يمبِ هاى دورمتغير بهدليل ماهيت عملكرد خود، انقطاع دورهاى

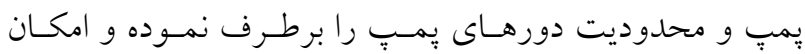

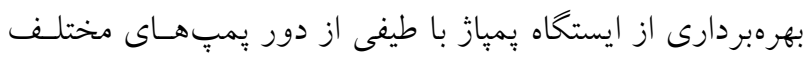

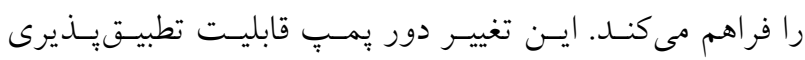

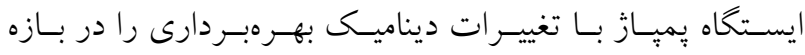

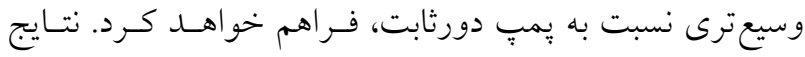

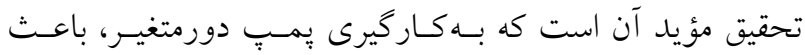
ذخيره انرزى مصرفى در طول دوره بهرهبردارى شــده اسـت. در رويكرد استفاده از بمّب دورمتغيـر، مصـارف انـرزى نسـبت بـهـ روش بهره بـردارى بـا پِمـِّ دورثابـت (در صـورت طراحسى و

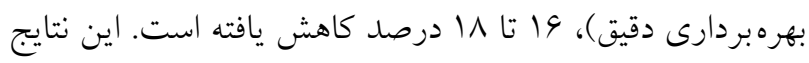

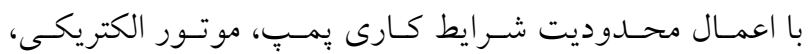
كثتاور بار و گشتاور اصطكاكى محاسبه شــه اسـت. بـهنظـر مىرسد تفاوت در ميزان صرفهجـويى انـرزى محاسـبه شــده در تحقيقات مختلف، به عواملى هم:جـون وضـعيت اوليسه سـامانه،

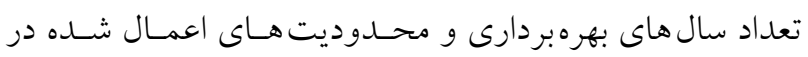

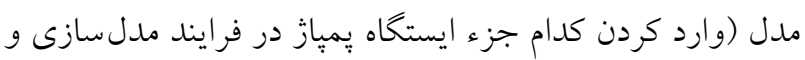

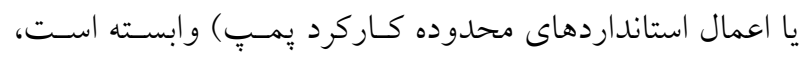




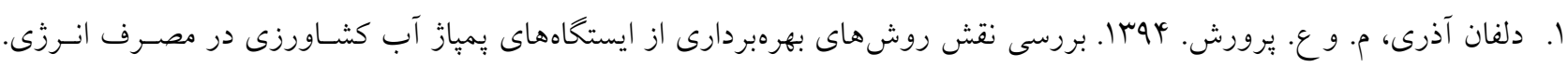

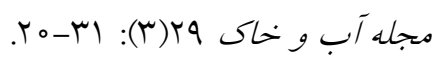

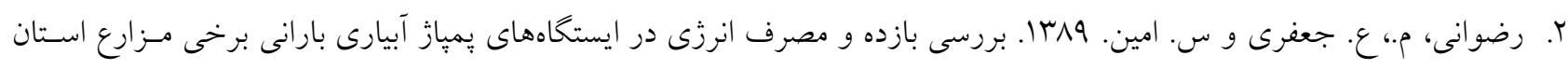

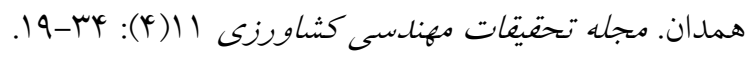

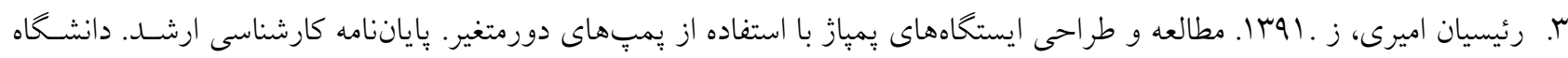

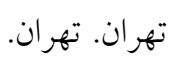

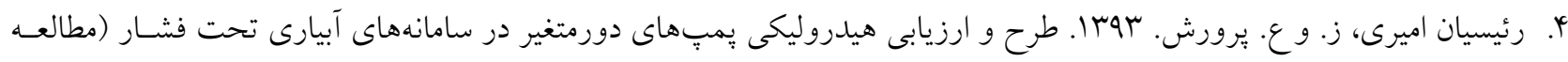

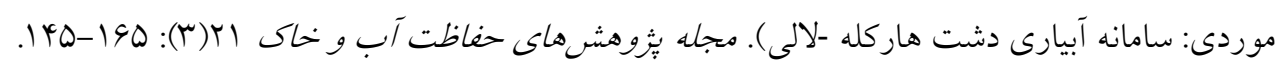

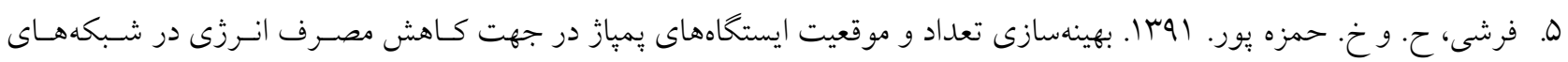

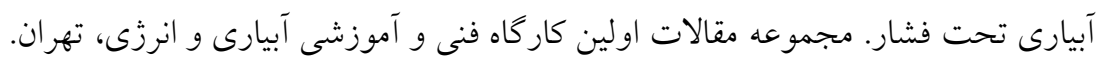

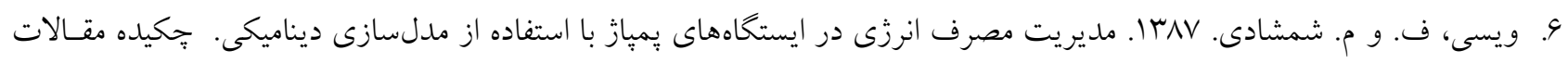

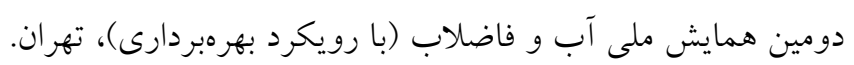

7. API 610. 2008. Centrifugal Pumps for Petroleum, Petrochemical and Natural Gas Industries, API Publishing Services, Washington DC, USA.

8. Bello, M. A., F. Martı'nez Alzamora, V. Bou Soler and H. J. Bartolı. 2010. Methodology for grouping intakes of pressurised irrigation networks into sectors to minimize energy consumption. Biosystems Engineering 105: 429438.

9. Carrillo-Cobo, M. T., J. A. Rodriguez-Diaz and E. Camacho-Poyato. 2010. The role of energy audits in irrigated areas. The case of 'Fuente Palmera' irrigation district (Spain). Agricultural Research 8(S2): 152-161.

10. Chávez, J. L., D. Reich, J. C. Loftis and D. L. Miles. 2010. Irrigation Pumping Plant Efficiency. Colorado State University Cooperative. Extension. Colorado.

11. Corominas, J. 2010. Agua y energia en el riego en la época de la sostenibilidad. Ingenieria del Agua 17(3): 219-233.

12. Diaz, R. J. A., L. Pérez-Urrestarazu, E. Camacho-Poyato and P. Montesinos. 2011. The paradox of irrigation scheme modernization: more efficient water use linked to higher energy demand. Agricultural Research 9(4): 1000-1008.

13. Fernandez-Pacheco, D., V. Ferrandez, J. Molina-Martinez and A. Ruiz-Canales. 2015. Performance indicators to assess the implementation of automation in water user associations: case study in southeast Spain. Agricultural Water Management 151: 87-92.

14. Gopal, M. 1984. Modern Control System Theory., NY: John Wiley and Sons, New York.

15. Hanson, B., Z. Weigand and S. Orloff. 1996. Performance of electric irrigation pumping plants using variable frequency drives. Irrigation and Drainage Engineering 122(3): 45-58.

16. Khadra, R., M. A. Moreno, H. Awada and N. Lamaddalena. 2016. Energy and hydraulic performance-based management of large-scale pressurized irrigation systems. Water Resource Manage 30(10): 3493- 3506.

17. Moreno, M. A., P. Planells, J. I. Co'rcoles, J. M. Tarjuelo and P. A. Carrio'. 2009. Development of a new methodology to obtain the characteristic pump curves that minimize the total cost at pumping stations. Biosystems Engineering 102: $95-105$.

18. New, L. L. and A. D. Schneider. 1988. Irrigation Pumping Plant Efficiencies-High Plains and Trans-Pecos Areas of Texas. Publication MP-1643. Texas Agricultural Experiment Station, Texas University System, College Station.

19. Smajstrla, A. G., D. S. Harrison, J. M. Stanley and D. Z. Haman. 2005. Evaluating Irrigation Pumping Systems. Agricultural Engineering Department. Fact Sheet AE-24. University of Florida. Gainesville.

20. Vera, J., R. Abadı'a, M. Mora and M. Rocamora. 2010. Eficiencia energe'tica de instalaciones de bombeo en pozos para extraccio'n de aguas de riego subterra'neas. In: Proceeding of the XXVIII Congreso Nacional de Riegos AERYD, Leo'n. 


\title{
Investigation of Energy Consumption in Agriculture Water Pumping Stations by Different Operation Methods (A Case Study: Ashrafiyeh Agro-Industry Irrigation System)
}

\section{A. Yousefgomrokchi ${ }^{*}$ and A. Parvaresh Rizi ${ }^{2}$}

(Received: July 19-2016 ; Accepted: July 15-2017)

\begin{abstract}
In the recent decades, due to the development of the pressurized irrigation systems, the relationship between the water and energy has been extended more than ever. So, according to problems due to the water shortage, energy saving is considered as one of the most important challenges in the agriculture section. In this study, by considering the capabilities of the pumping systems, variable speed pumps have been examined in an agro-industrial region of Ashrafiyeh (Qazvin province, Iran) with an area of 85 ha. The energy consumption during the ten-year operation was analyzed in the five operation scenarios by the MATLAB/SIMULINK software. The results showed that the consumed electrical energy by using variable speed pumps was approximately decreased up to about 18 percent, as compared to the fixed speed pumps. The results of the evaluation of the consumed energy showed that the current operation circumstance increased energy losses up to about 60 percent, as compared to the other operation methods. The results also revealed that the overall energy efficiency for the current operation circumstance was 52 percent ( 78 percent of Nebraska Performance Criteria).
\end{abstract}

Keywords: Energy saving, Modeling, Nebraska criteria, SIMULINK, Variable speed pump

1. Agricultural Engineering Research Department, Qazvin Agricultural and Natural Resources, Research and Education Center, AREEO, Qazvin, Iran.

2. Irrigation and Reclamation Engineering, Department of Agriculture and Natural Resources Campus. University of Tehran, Tehran, Iran.

*: Corresponding Author, Email: a.gomrokchi@areeo.ac.ir 